\title{
Differentiating the Terminology in the field of Public Administration: Functional Approach
}

\author{
O. I. Vanivska ${ }^{1}$, O. M. Vanivska ${ }^{2}$ \\ ${ }^{1}$ Ukrainian and Foreign Languages Department at Lviv Regional Institute for Public Administration of the \\ National Academy for Public Administration under the President of Ukraine (LRIPA NAPA) \\ ${ }^{2}$ Department of Foreign Languages at Ukrainian National Forestry University, Lviv, Ukraine \\ *Corresponding author. E-mail: vanivskaolga@gmail.com
}

Paper received 24.10.18; Accepted for publication 29.10.18.

\section{https://doi.org/10.31174/SEND-Ph2018-182VI53-16}

\begin{abstract}
The article speaks about the real usage of the key terms in the field of Public administration, which at first sight may seem very similar and be considered interchangeable, i.e. two pairs of the terms public management vs public administration and public service vs civil service. Using the authentic language data of the British National Corpus and while analyzing different genres of written and spoken language there are suggested the results of the research, which show the difference in the pragmatic, functional, sociolinguistic, and quantitative characteristics of the above mentioned terms.
\end{abstract}

Keywords: civil service, lexical units, public administration, public service, public management, terms in Public administration.

During decades a lot of scientists and researchers have been studying different languages trying to describe and highlight their ideas on the important issues of structural, discursive, pragmatic, cognitive, functional characteristics of lexical units and all these studies are still topical as far as everything changes, we find new words and word combinations that appear according to the necessities of today's frantic time of globalization, new technologies, businesses and communication.

The functional approach to studying language is one of the most interesting aspects of modern linguistics. Great attention is paid to nominative and pragmatic functions of language units [1]. The ability of language to express different things by means of the same units or vice versa, the ability of different terms to nominate the same or very similar things and notions is possible because of their multi semantic features, pragmatic characteristics, matters of use, etc. The functional approach is closely related to be the second paradigm of psychology. It is based on the function of mental processes and involves consciousness [8]. It is also reasoned that in functional approach the mental act of consciousness must be an important biological function [6]. In the process of second language acquisition functional approaches are similar to Noam Chomsky's Universal Grammar theory. Here the focus is on the direct use of language in real situations, conditions within the relevant knowledge and competence. And the topicality of our research is stipulated by the necessity to find out in what contexts of English language, using the authentic language data of British National Corpus, are key terms in the field of Public administration used and what is the difference between them, the peculiarities of their functional characteristics and usage in different genres of spoken and written English, since we take two pairs of very similar terms in Public administration, i.e. public management vs public administration and public service vs civil service.

Resent research and publications analysis. Different aspects of linguistics have been studied by such well-known linguists as, for instance, Noam Chomsky, who revolutionized the field of linguistics by treating language as a uniquely human, biologically based cognitive capacity; Charles Bally, who is mostly known for his work in comparative stylistics and phraseology, he developed a descriptive methodology for linguistics based on translation and functional equivalence; and we also appeal to the idea of the Prague school approach, which is about the combination of structuralism with functionalism. And it is necessary to mention German psychologist Karl Bühler, who recognized three general kinds of function fulfilled by language: cognitive, expressive and conative. Taking into account all the theoretical aspects suggested by famous scientists and linguists, after facing different misunderstandings and difficutlies in the usage and differentiation of the above mentioned key terms in Public administration we consider it vital to draw attention to the analysis of the factual use of lexical units in various contexts of written and spoken language as far as this issue has not been studied yet.

Paper objective concerns the study of the key terms in the field of Public administration in different genres of written and spoken language, analyzing their pragmatic and sociolinguistic features, revealing the difference of their functioning, including quantitative data.

Materials and methods. As the material of our research we use the database of the British National Corpus (BNC), which consists of 100 million word collection of samples of written and spoken language from a wide range of sources. In order to carry out the research we have taken two pairs of very similar terms in Public administration, i.e. public management vs public administration and public service vs civil service because of the importance of these terms for the field and there were applied various methods: the method of differentiation to define the meaning of the terms, pragmalinguistic and sociolinguistic method to study the specifics of the usage of lexical units, structural and lexical-semantic method to analyze the peculiarities of using the terms in different genres of language, the chronological method to study the publication dates of the terms, and also the quantitative method to highlight the quantitative parameters of all the key terms and find out their ergonomic features in order to understand whether they are relevant for the general communication.

Paper main body. To be successful, public administrators need to be able to analyze and evaluate policies, and to understand analyses and evaluations. When the field of Public administration is explored, one may find the terms public management and public administration used interchangeably. Nevertheless, these terms are not totally interchangeable. Even if in some situations these terms may be used and are used one instead of another. According to some definitions, public management looks closely at the implementa- 
tion of policies, procedures, and actions of administration in the light of management in private and non-profit sectors. And public administration traditionally has been connected to government offices or public service. A closer look at administration and management reveals various degrees of difference between them [7] and their usage.

Public administration is the implementation of government policy and also an academic discipline that studies this implementation and prepares civil servants for working in the public service. Public management is the most rapidly developing subfield in public administration, establishing a core position within the field alongside the study of public policy and public governance [3].

Both terms are well-known, but their usage, especially from the quantitative point of view, is totally different as far as according to the BNC data public administration is used in 84 texts, and there are 200 solutions of its usage. And as for public management, it is used only in 5 texts and there are generally 18 solutions of its usage. For example: The critical area of public management is the management of organizational interdependence, for example in the delivery of services or in the management of the budgetary process (domain: social science). Public management may be the simplest solution (domain: commerce). However, there still remains an important field for public administration by local elected councils (domain: world affairs). In comparison with these industries, retail trade and public administration have experienced limited job growth (domain: commerce). How lucky they were to have the English language, for instance, plus the system of law and public administration (domain: leasure). This course provides a valuable preparation for entry to areas such as industry and commerce, public administration, education, and the media. Finally, the workforce in public administration showed a marked rise, connected with the expansion of public expenditure programmes and the development of state apparatuses concerned with industrial consultation and intervention (domain: social science). The two are complementary but different aspects of public administration (applied science).

While analyzing the term public management, which is surprisingly low-used, it is clear that in most cases it is present in academic prose, in written books and periodicals. The social science domain dominates here. There is no example of this term's usage in spoken language, only written. And all of the texts are marked as of high difficulty. Speaking about sociolinguistic characteristics of this term, there is no surprise that only adults use it, the author's age in all examples is between 45-59, but while analyzing the sex of the author it was found that in almost all cases these were females. The publication date of the term public management is between 1985-1993.

As it was mentioned above, the term public administration is used far more often than public management. Moreover, there is one example of its usage in spoken language, for example: Anne Stevens is an expert on public administration, and specializes in French affairs (radio broadcast, recorded in educational context; interaction type: dialog). Similar to the term public management, public administration is used mostly in academic prose (120 solutions) and also in nonacademic prose (55 solutions) and other published materials; almost all examples are taken from written books and periodicals; there are 7 examples taken from newspapers, such as: He was an active supporter of national and regional insti- tutes of public administration, and was a founding member of the African Association of Public Administration and Management (AAPAM), which links senior civil servants from many African countries. In recognition of the general interest in avoiding the disruptive effect of such proceedings on the public administration no one could apply for judicial review unless they had successfully applied ex parte for leave. The analysis of the domain shows that the term public administration is mostly used in the sphere of social science (100 solutions), but also it is present in world affairs sphere (72 solutions), commerce and finance (20 solutions), applied science (6 solutions) and arts ( 1 solution). And not all of the texts are marked as of high difficulty as it was mentioned above concerning the term public management. So, if to speak about written difficulty, 137 solutions are marked as of medium difficulty, 53 - high and 9 of them are of low difficulty. From the sociolinguistic point of view, definitely, the term public administration is used almost in all cases by adults and only 1 solution is mentioned as used by a teenager. As for the author's age, it starts from 35 and finishes at $60+$, but there are a lot of solutions, where the author's age is unknown, and as for the author's sex, here, on the contrary to the previous term, males dominate. The publication date of the term public administration doesn't limit between the years of 1985-1993, but there are also solutions between the years 1975-1984: In public administration, on the other hand, objectives are more complicated, with the intentions of legislators being much less straightforward and those in charge having discretion in implementing policy. It covers fields such as politics, education, public administration, commerce, industry, defense, law and order, health care, arts, sciences, technology, home and leisure. Also there are those examples, the publication date of which is unknown.

As far as the second group of terms we are studying is concerned, according to Business dictionary, "civil service is a body of government employees entrusted with the administration of the country, and mandated to carry out the policy of the government of the day". While referring to the term "public service", there are given the following definitions: "1) service provided or supported by a government or its agencies; 2) agency involved in providing public service for or on behalf of a government"'[2].

Thus, public service job is one where a person works for a government unit. This could be an employee in a local district or a maintenance worker who is responsible for maintaining sports fields for the country or city government. These workers provide a service to the public. On the other hand, a civil service job is also a government job, but with civil service jobs, a person must pass a test to show that he or she is qualified for the position. The person cannot get the job because of connections with the person who hires workers. So it is widely considered that public service includes all jobs, which relate to the government providing goods and services to public, but civil service includes only professional positions and it refers to a system where jobs and promotions are earned by merit [4].

Civil service and public service are very similar concepts. In fact, both services are offered by the government to all citizens or to all persons under the government's jurisdiction and both aim at improving the country's social environment. Civil service and public service are services provided by the government to all citizens and to all individuals under the government's jurisdiction. Civil service is performed by the 
highest skilled individuals who have the responsibility of implementing public policies, of providing services to the public and of serving the interests of the country. Conversely, public service is performed by individuals who do not need to be highly qualified and can be done on a voluntary basis. Civil servants include members of the government, members of various government department and members of embassies and consulates. Public servants include firefighters and police officers, but also volunteers and privates that provide services to the community and to the neediest segments of society [5].

Both terms are well known, but there is a difference in their usage in written and spoken language, especially from the quantitative point of view, as far as according to the BNC data civil service is used in 387 texts, and there are 1180 solutions of its usage. But public service is used in 260 texts and there are only 575 solutions of its usage. For example: $I$ was employed by the civil service to carry out special projects. Labour will expect all staff in the civil service, and publicly-owned industries to carry out each policy irrespective of their point of view. He retired in 1982 in some frustration with the civil service before eventually becoming director-general of the Institute of Directors. For instance, one manager in a public service agency had a subordinate who was not really effective at supervising others and was resistant to suggestions for improvement. A publicly funded, public service organization such as the BBC would need to be treated differently from a privately owned quality paper or a Trust-owned Guardian. This fitted perfectly well into the public service world, but in practice it was considerably diluted for viewers by the networking arrangements of the four (later five) larger companies.

While analyzing these two terms we can clearly see that public service is nearly twice less used than civil service. Unlike previously researched terms, both civil service and public service are mostly used in non-academic and academic prose and biography, also they are found in newspapers, written books, and periodicals. It seems natural not to meet large amounts of solutions of using these terms in fiction and verse because of their semantic and pragmatic features. When examining the transcribed speech, we find out that the term public service is not used in everyday spoken conversations, but is even more often used in spoken contexts (meets in 35 solutions - that is $6,5 \%$ of cases) of educational (3), business (15), public/institutional (13) and leisure (4) spheres than the term civil service (meets in 48 solutions - that is $4 \%$ of cases), especially if to take into account the general amount of found solutions of their usage. And unlike the public service, the term civil service is more common for other spoken contexts and also used in everyday conversations, namely: spoken conversations (7), educational (17), business (4), public/institutional (18) and leisure (2). Another functional difference in using these terms concerns the interaction type, as far as public service is used fifty-fifty in monologues (18) and dialogues (17), but civil service is mostly used in dialogues (41).

If to speak about written difficulty, the majority of the texts are marked as of medium difficulty, but while comparing these two terms we have found that one-third of the texts with the term civil service is given as of high difficulty. On the other hand, almost the half of the texts with the term public service is marked as of high difficulty. That's why there is no surprise that the audience, who read or use these terms in most cases are adults.

Conclusions. In conclusion, it is necessary to underline the fact that the functional load of all the studied terms clearly responds to their pragmatic and semantic characteristics. All of them are not relevant for the general communication, which was proved by the research of the sociolinguistic peculiarities. Even if at first sight the terms seem to have similar meanings and be interchangeable, the above given results of the research show that they are rather different, and it was surprising to find out that the quantitative difference is huge. Further studies will also concern the real use of other well-known terms in the field of Public administration, while analyzing the authentic language data.

\section{REFERENCES}

1. Балли Ш. Общая лингвистика и вопросы французского языка / Шарль Балли. - М.: Изд-во иностранной литературы, 1955 $-416 \mathrm{c}$.

2. Business Dictionary [Online]. $\quad-\quad$ Available: http://www.businessdictionary.com/

3. Dictionary [Online]. http://dictionary.infoplease.com/public-administration

4. Difference between civil service and public service [Online]. Available: https://www.enotes.com/homework-help/differencebetween-civil-service-public-service-163471

5. Difference Between Civil Service and Public Service [Online]. Available:

http://www.differencebetween.net/miscellaneous/politics/differen ce-between-civil-service-and-public-service/

6. Schacter D. S., Gilbert, D. T., Wegner, D. M. Psychology: 2nd Edition. - New York: Worth Publishers, 2011. - 800 p.

7. What is the Difference Between Public Management and Public Administration? // Get a Real Degree [Online]. - Available: http://getarealdegree.com/what-is-the-difference-between-publicmanagement-and-public-administration/

8. William James and Functionalism [Online]. - Available: http://www.psych.utah.edu/gordon/Classes/Psy4905Docs/Psych History/Cards/James.html

\section{REFERENCES}

1. Bally, Ch. General linguistics and issues of French / Charles Bally. - Moscow: Publishing house of foreign literature, 1955. $416 \mathrm{c}$.

2. Business Dictionary [Online]. $-\quad$ Available: http://www.businessdictionary.com/

3. Dictionary [Online]. http://dictionary.infoplease.com/public-administration

4. Difference between civil service and public service [Online]. Available: https://www.enotes.com/homework-help/differencebetween-civil-service-public-service-163471

5. Difference Between Civil Service and Public Service [Online]. Available:

http://www.differencebetween.net/miscellaneous/politics/differen ce-between-civil-service-and-public-service/

6. Schacter D. S., Gilbert, D. T., Wegner, D. M. Psychology: 2nd Edition. - New York: Worth Publishers, 2011. -800 p.

7. What is the Difference Between Public Management and Public Administration? // Get a Real Degree [Online]. - Available: http://getarealdegree.com/what-is-the-difference-between-publicmanagement-and-public-administration/

8. William James and Functionalism [Online]. - Available: http://www.psych.utah.edu/gordon/Classes/Psy4905Docs/Psych History/Cards/James.html 